ORIGINAL ARTICLE

\title{
Use of multiple displacement amplification to amplify genomic DNA before sequencing of the $\alpha$ and $\beta$ haemoglobin genes
}

\author{
M Mai, J D Hoyer, R F McClure
}

J Clin Pathol 2004;57:637-640. doi: 10.1136/jicp.2003.014704

See end of article for authors' affiliations ......................

Correspondence to: Dr R F McClure, Department of Laboratory Medicine and Pathology, Mayo Clinic, 200 First Street SW, Rochester, MN, 55905, USA; mcclure. rebecca@mayo.edu

Accepted for publication 21 December 2003

\begin{abstract}
Aims: To evaluate the technique of multiple displacement amplification (MDA) for whole genome amplification from small volume blood samples before sequencing in a clinical test to identify haemoglobin gene mutations.

Methods: Phage $\phi 29$ DNA polymerase was used to perform MDA, starting with either $1 \mu$ l of blood or $1 \mathrm{ng}$ of previously isolated blood DNA from 23 patients. The amplified products were then evaluated using a clinical test that involves sequencing the haemoglobin genes to detect mutations. The results were compared with the current clinical test method that uses genomic DNA isolated using column based technology.

Results: The MDA technique produced large quantities (theoretically approximately $2 \mathrm{mg}$ ) of DNA. The amplification procedure was extremely easy and took about four hours (less than one hour of hands on technician time and three hours for amplification). When MDA products were used in the same clinical test protocol as genomic DNA isolated using column technology, there was $100 \%$ concordance for detection of a variety of point mutations in the $\alpha 1, \alpha 2$, and $\beta$ globin genes.

Conclusions: The MDA technique is useful for overcoming the problem of insufficient genomic DNA in clinical specimens requiring haemoglobin gene sequencing and could be useful for other clinical applications.
\end{abstract}

O btaining a sufficient amount of high quality DNA from clinical samples to perform molecular tests is frequently a challenge. In our practice, DNA sequencing of globin genes is often indicated, but not possible because of insufficient blood remaining after the initial haemoglobin protein studies. This is particularly true for samples taken from infants, where obtaining the recommended volume of blood for testing is difficult. Our standard procedure includes genomic DNA extraction using column based technology, followed by globin gene specific polymerase chain reaction (PCR) amplification to provide a template for sequencing. In our experience with clinical specimens, genomic DNA from small numbers of cells is lost during column isolation and it is difficult to perform gene specific PCR directly from genomic DNA released from very small numbers of nucleated cells. Thus, it would be useful to have a reliable method for genomic DNA amplification, so that testing could be performed on a small number of nucleated cells.

\begin{abstract}
"In our practice, DNA sequencing of globin genes is often indicated, but not possible because of insufficient blood remaining after the initial haemoglobin protein studies"
\end{abstract}

PCR based whole genome amplification methods have been described, ${ }^{12}$ although they have not been widely accepted as useful for amplifying clinical samples because of their complexity and lack of replication accuracy. Recently, phage $\phi 29$ DNA polymerase has been used in a technique called multiple displacement amplification (MDA) to perform quick and accurate amplification of total genomic DNA from small numbers of cells. ${ }^{3}$ Because of the high processivity and high fidelity of the polymerase, many copies of double stranded linear DNA, each greater than $10 \mathrm{~kb}$ in length, can be generated in the presence of random primers under isothermal conditions. Using the MDA technique, we easily produced large quantities of DNA from either $1 \mu \mathrm{l}$ of peripheral blood (approximately 5000 nucleated cells) or $1 \mathrm{ng}$ of previously isolated genomic DNA. We then used the amplified DNA to obtain reliable results in our clinical test for $\alpha$ and $\beta$ globin gene sequencing.

\section{METHODS \\ Samples}

Twenty three peripheral blood specimens sent to the Mayo Clinic laboratory for haemoglobin testing were used in a nonblinded, retrospective analysis. The specimens had been stored at room temperature for variable amounts of time (range, 2-7 days) and 11 of the samples had been frozen $\left(-20^{\circ} \mathrm{C}\right.$; range, $2-18$ months) before use.

\section{Whole genome amplification using MDA}

The kit (REPLI-g 625s) from Molecular Staging Inc (New Haven, Connecticut, USA) was used according to the manufacturer's instructions. Briefly, $1 \mu \mathrm{l}$ of blood (approximately 5000 nucleated cells) was diluted in $34 \mu \mathrm{l}$ of phosphate buffered saline, lysed by the addition of $35 \mu \mathrm{l}$ of Fast Lysis solution, and neutralised by the addition of $35 \mu \mathrm{l}$ of Lysis Stop buffer. A $2.5 \mu \mathrm{l}$ aliquot of the lysis product was then mixed with 40 units $(0.5 \mu \mathrm{l})$ of $\phi 29$ DNA polymerase, $12.5 \mu \mathrm{l}$ of random primers and dNTPs, and $34.5 \mu \mathrm{l}$ of distilled $\mathrm{H}_{2} \mathrm{O}$ to a final volume of $50 \mu \mathrm{l}$ and incubated at $30^{\circ} \mathrm{C}$ for 16 hours. In some cases, MDA was performed starting with genomic DNA isolated using column technology (see below). In these cases, the procedure was modified such that $1 \mathrm{ng}$ of

Abbreviations: MDA, multiple displacement amplification; PCR, polymerase chain reaction 
Table 1 PCR and sequencing primers for $\alpha$ and $\beta$ haemoglobin genes

\begin{tabular}{|c|c|c|}
\hline Gene & Primer & Primer sequence \\
\hline \multirow[t]{12}{*}{$\alpha$ Globin genes } & PCR primers & \\
\hline & $A G-F$ & $5^{\prime} \operatorname{ccc}$ gcg ccc caa gca taa ac \\
\hline & AGI-R & $5^{\prime}$ ctg gca cgt ttg ctg agg gaa aa \\
\hline & AG2-R & $5^{\prime}$ tgg cac att ccg gga tag aga \\
\hline & $\begin{array}{l}\text { Sequencing } \\
\text { primers }\end{array}$ & \\
\hline & AGS1-F & $5^{\prime}$ caa gca taa acc ctg gc \\
\hline & AGS1-R & $5^{\prime}$ gag cog tgg ctc agg tcg \\
\hline & AGS2-F & $5^{\prime}$ caa ccg tcc tgg ccc cgg \\
\hline & ASG2-R & $5^{\prime}$ gtg aac tcg geg ggg agg $t$ \\
\hline & ASG3-F & $5^{\prime} \mathrm{cgg}$ gtt gcg gga ggt gta g \\
\hline & AGIS3-R & $5^{\prime}$ tgc tga ggg aaa aaa ctc agg \\
\hline & AG2S3-R & $5^{\prime}$ tcc ggg ata gag aga acc $c$ \\
\hline \multirow[t]{14}{*}{$\beta$ Globin gene } & PCR primers & \\
\hline & Exon 1-F & $5^{\prime}$ gta cgg ctg tca tca ctt aga c \\
\hline & Exon 1-R & $5^{\prime}$ aaa ccc aag agt ctt ctc tgt $c$ \\
\hline & Exon 2-F & $5^{\prime}$ act ggg cat gtg gag aca gag a \\
\hline & Exon 2-R & $5^{\prime}$ tgt ttc cca Hc taa act gta $\mathrm{c}$ \\
\hline & Exon 3-F & $5^{\prime}$ cat att get aat age age tac a \\
\hline & Exon 3-R & $5^{\prime}$ ctc cca cat tcc ctt ttt agt \\
\hline & $\begin{array}{l}\text { Sequencing } \\
\text { primers }\end{array}$ & \\
\hline & Exon $1-\mathrm{F}$ & $\begin{array}{l}5^{\prime} \text { aca ccc tag ggt tgg cca atc tac } \\
\text { tc }\end{array}$ \\
\hline & Exon 1-R & $5^{\prime}$ atg ccc agt ttc tat tgg tct cct taa \\
\hline & Exon $2-\mathrm{F}$ & $5^{\prime} \mathrm{ttg}$ ggt ttc tga tag gca ctg act ct \\
\hline & Exon 2-R & $5^{\prime}$ ttc tcc cct tcc tat gac atg aac tta \\
\hline & Exon 3-F & $5^{\prime}$ taa ggc tgg att att ctg agt $c$ \\
\hline & Exon 3-R & $\begin{array}{l}5^{\prime} \text { gac tta ggg aac aaa gga acc } \\
\text { ttt aat a }\end{array}$ \\
\hline
\end{tabular}

DNA was mixed directly with the enzyme and primers and incubated as described above.

\section{Quantitative and qualitative analysis of the MDA products}

The MDA products were quantitated using a fluorescence based method that is specific for double stranded DNA (PicoGreen ${ }^{\circledR}$; Molecular Probes, Eugene, Oregon, USA). Aliquots $(5 \mu \mathrm{l})$ of the MDA product were also analysed using agarose gel electrophoresis (1.0\% agarose, $100 \mathrm{~V}, 60$ minutes, stained with ethidium bromide) and the products visualised using the Alpha Imager gel documentation system (San Leandro, California, USA).

\section{DNA isolation using column technology}

The Wizard genomic DNA purification kit (Promega, Madison, Wisconsin, USA) was used to isolate genomic DNA from 0.3 to $3 \mathrm{ml}$ of whole, never frozen blood using the manufacturer's instructions.
Table 2 DNA yield after MDA

\begin{tabular}{|c|c|c|c|c|}
\hline Patient & Specimen & $\begin{array}{l}\text { Blood } \\
\text { volume or } \\
\text { DNA } \\
\text { amount }\end{array}$ & $\begin{array}{l}\text { Yield/ } \\
\text { reaction* } \\
(\mu \mathrm{g})\end{array}$ & $\begin{array}{l}\text { Theoretical total } \\
\text { yield } \dagger(\mu \mathrm{g})\end{array}$ \\
\hline 1 & $\begin{array}{l}\text { Never frozen } \\
\text { WB }\end{array}$ & $1 \mu l$ & 45 & 1875 \\
\hline 2 & $\begin{array}{l}\text { Never frozen } \\
\text { WB }\end{array}$ & $1 \mu l$ & 48 & 2000 \\
\hline 3 & $\begin{array}{l}\text { Never frozen } \\
\text { WB }\end{array}$ & $1 \mu l$ & 44 & 1833 \\
\hline 4 & $\begin{array}{l}\text { Never frozen } \\
\text { WB }\end{array}$ & $1 \mu l$ & 53 & 2208 \\
\hline 5 & Frozen WB & $1 \mu l$ & 53 & 2208 \\
\hline 6 & Frozen WB & $1 \mu l$ & 50 & 2083 \\
\hline 7 & Frozen WB & $1 \mu l$ & 50 & 2083 \\
\hline 8 & Frozen WB & $1 \mu l$ & 52 & 2167 \\
\hline 9 & Frozen WB & $1 \mu l$ & 50 & 2083 \\
\hline 10 & Frozen WB & $1 \mu l$ & 55 & 2292 \\
\hline 11 & Frozen WB & $1 \mu l$ & 56 & 2333 \\
\hline 12 & Frozen WB & $1 \mu l$ & 57 & 2375 \\
\hline 13 & Frozen WB & $1 \mu l$ & 57 & 2375 \\
\hline 14 & Frozen WB & $1 \mu l$ & 48 & 2000 \\
\hline 15 & Frozen WB & $1 \mu l$ & 48 & 2000 \\
\hline 16 & DNA & $1 \mathrm{ng}$ & 51 & \\
\hline 17 & DNA & $1 \mathrm{ng}$ & 50 & \\
\hline 18 & DNA & $1 \mathrm{ng}$ & 50 & \\
\hline 19 & DNA & $1 \mathrm{ng}$ & 59 & \\
\hline 20 & DNA & $1 \mathrm{ng}$ & 57 & \\
\hline 21 & DNA & $1 \mathrm{ng}$ & 46 & \\
\hline 22 & DNA & $1 \mathrm{ng}$ & 49 & \\
\hline 23 & DNA & $1 \mathrm{ng}$ & 56 & \\
\hline
\end{tabular}

*Each reaction contained only $2.5 \mu \mathrm{l}$, equal to $2.4 \%$ of the $1 \mu \mathrm{l}$ WB lysis product (see methods); the theoretical total yield is the calculated yield that would have been obtained if the entire $1 \mu \mathrm{l}$ of WB had been amplified.

MDA, multiple displacement amplification; WB, whole blood.

\section{Sequencing of $\alpha$ and $\beta$ haemoglobin genes}

Table 1 shows the primers used for PCR amplification and subsequent sequencing of the $\alpha$ and $\beta$ haemoglobin genes. PCR was performed in a $25 \mu \mathrm{l}$ reaction volume containing $50 \mathrm{mmol} /$ litre $\mathrm{KCl}, 10 \mathrm{mmol} /$ litre Tris/ $\mathrm{HCl}(\mathrm{pH} \mathrm{8.3})$, $200 \mathrm{umol} /$ litre each dNTP, $1.5 \mathrm{mmol} /$ litre $\mathrm{MgCl}_{2}, 0.2 \mu \mathrm{mol} /$ litre each primer, 1.25 units of hot start Taq DNA polymerase, and $5 \mu \mathrm{l}$ of Q-solution (US-Qiagen, Valencia, California, USA). The reactions were amplified in an MBS Satellite thermal cycler (Thermal Hybaid, Waltham, Massachusetts, USA) with an initial incubation at $95^{\circ} \mathrm{C}$ for 15 minutes, followed by 35 cycles of $94^{\circ} \mathrm{C}$ for 30 seconds and $61^{\circ} \mathrm{C}$ for one minute, with a single final incubation of $72^{\circ} \mathrm{C}$ for one minute. Sequencing was then performed using the dye terminator method with fragment analysis by capillary electrophoresis on the ABI 377 (Applied Biosystems, Foster City, California,
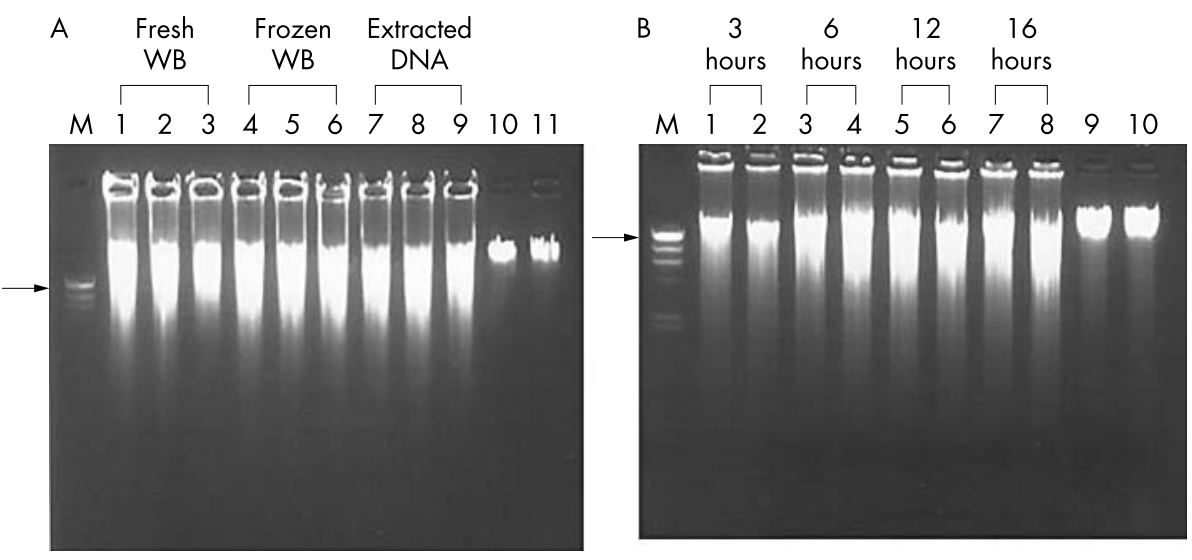

Figure 1 Agarose gel electrophoresis of multiple displacement amplification using MDA products. The arrow designates a marker fragment of $23 \mathrm{~kb}$ (A) Lanes 1-9 contain MDA products with the starting sample type shown above the lanes. Lanes 10 and 11 contain non-amplified genomic DNA (1.25 $\mathrm{\mu g}$ each) extracted using the column technique (see methods). (B) Lanes 1-8 contain MDA products and show the effect of decreasing amplification incubation time (see methods). Lanes 10 and 11 contain non-amplified genomic DNA $11.25 \mu \mathrm{g}$ each) extracted using the column technique (see methods). WB, whole blood. 
Patient 19

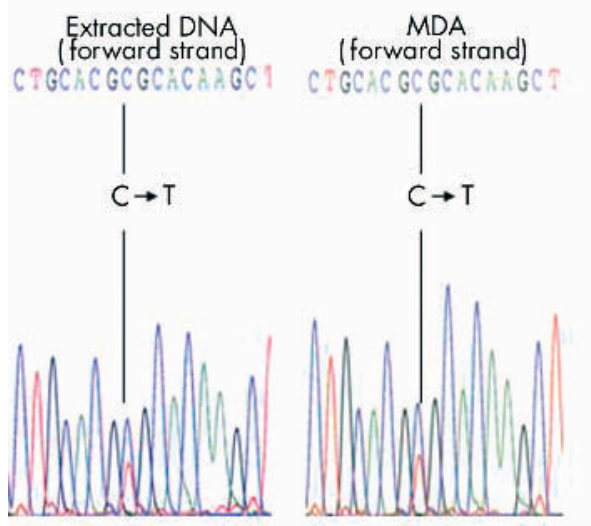

Patient 22

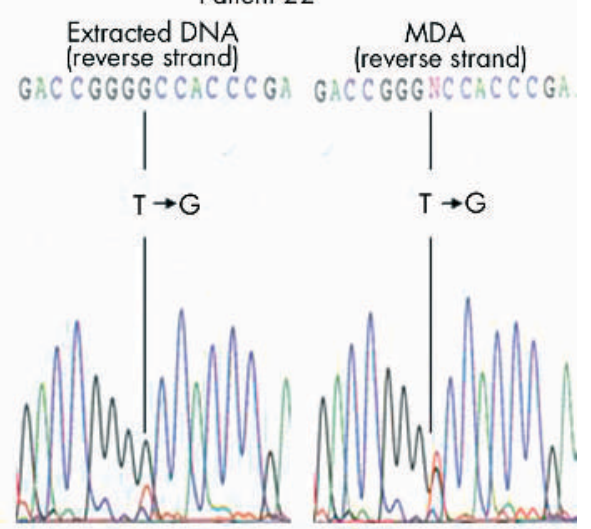

Figure 2 Representative sequencing traces showing concordant point mutation detection in two patients using DNA extracted with the column method and DNA amplified by multiple displacement amplification (MDA) as templates.
USA) using Chromas 2.0 sequence analysis software (Technelysium Pty Ltd, Tewontia, Australia). Both strands of DNA in each specimen were sequenced.

\section{RESULTS}

Quantitation using the fluorescence based method revealed that each reaction, starting with either never frozen or previously frozen whole blood, produced approximately $50 \mu \mathrm{g}$ of double stranded DNA (range, 44-59 $\mu$ g; table 2). Because only approximately $2.4 \%$ of the DNA released during the cell lysis step was amplified (see methods), the theoretical total yield from the amplification of $1 \mu \mathrm{l}$ of whole blood was estimated to be approximately $2 \mathrm{mg}$ (table 2 ). Similar yields were obtained when the starting template was $1 \mathrm{ng}$ of genomic DNA isolated using column technology. Specimen age before processing did not appear to have a significant affect on the yield. Qualitative analysis of the MDA products using agarose gel electrophoresis (fig 1) revealed that the amplified fragments were mostly greater than $20 \mathrm{~kb}$ and showed smaller average fragment size than the genomic DNA extracted using column technology (fig 1A). In addition, although the manufacturer's recommendation for MDA incubation was 16 hours, as little as three hours of incubation was sufficient to produce a substantial amount of DNA (fig 1B).

In each sample, the DNA sequence from both strands showed a normal haemoglobin gene sequence in the entire region expected to be normal, and the expected mutations were correctly identified (table 3; fig 2). There was 100\% concordance between the sequences obtained using MDA products as a template and those obtained using DNA extracted by the column method as a template.

\section{DISCUSSION}

Our results show that MDA is a useful method for amplifying very small amounts of genomic DNA before haemoglobin gene sequencing. Reliable results were obtained using whole blood specimens subjected to a variety of pretest conditions, including variable lengths of room temperature incubation, freezing, or previous genomic DNA extraction using a column based method. As little as $1 \mu \mathrm{l}$ of whole blood or $1 \mathrm{ng}$ of previously extracted DNA were adequate amounts of starting material, making the procedure useful for even the smallest clinical samples available.

Although no DNA purification was performed when whole blood was amplified, the small amount of residual cell debris

Table 3 Sequencing results of extracted DNA and MDA products

\begin{tabular}{|c|c|c|c|c|c|c|}
\hline Patient & Mutation name & Gene & $\begin{array}{l}\text { Nucleotide } \\
\text { position }\end{array}$ & Codon number & Normal sequence & Mutation identified $^{*}$ \\
\hline 5 & $\mathrm{Hb}$ Buffalo & $\alpha 1$ & 424 & 89 & CAC & CAG \\
\hline 7 & Hb G-Pest & $\alpha 1$ & 377 & 74 & GAC & $A A \bar{C}$ \\
\hline 8 & Hb Fuchu-I & $\alpha 1$ & 371 & 72 & CAC & $\overline{\mathrm{TAC}}$ \\
\hline 19 & $\mathrm{Hb}$ Columbia Missouri & $\alpha 1$ & 420 & 88 & GCG & G̈TG \\
\hline 22 & $\mathrm{Hb}$ Bassett & $\alpha 1$ & 438 & 94 & GAC & GC̄C \\
\hline 20 & $\mathrm{Hb}$ Buffalo & $\alpha 1$ & 424 & 89 & CAC & CĀG \\
\hline 3 & $\mathrm{Hb}$ Manitoba & $\alpha 2$ & 605 & 102 & AGC & CḠ \\
\hline 6 & Poly A signal mutation & $\alpha 2$ & 819 & & AATAAA & $\bar{A} A T A A G$ \\
\hline 11 & $\mathrm{Hb}$ Chicago & $\alpha 2$ & 705 & 136 & CTG & ATG - \\
\hline 12 & Constant Spring & $\alpha 2$ & 723 & 142 & TAA & $\bar{C} A A$ \\
\hline 9 & Intron mutation & $\alpha 2$ & 509 & & G & $\overline{\mathrm{T}}$ \\
\hline 14 & $\mathrm{Hb}$ Coen & $\alpha 2$ & 694 & 132 & GTG & GGG \\
\hline 15 & $\mathrm{Hb}$ Beth Israel & $\beta$ & 488 & 102 & AAC & $A \bar{G} C$ \\
\hline 1 & $\mathrm{HbE}$ & $\beta$ & 129 & 26 & GAG & $A \bar{A} G$ \\
\hline 2 and 4 & $\mathrm{Hb} \mathrm{S}$ & $\beta$ & 70 & 6 & GAG & GTG \\
\hline 10 & $\mathrm{Hb}$ Austin & $\beta$ & 304 & 40 & AGG & $\bar{A} \bar{G} \underline{C}$ \\
\hline 13 & Intron mutation & $\beta$ & 148 & $\backslash$ & G & $C^{-}$ \\
\hline 16 & $\mathrm{Hb}$ Atlanta & $\beta$ & 407 & 75 & CTG & CCG \\
\hline 17 & $\mathrm{Hb}$ Athens GA & $\beta$ & 303 & 40 & AGG & $A \bar{A} G$ \\
\hline 18 & $\mathrm{Hb} \beta^{0}$ Thal. (stop codon) & $\beta$ & 299 & 39 & CAG & $T \overline{A G}$ \\
\hline 21 & Promoter mutation (position -29) & $\beta$ & -29 & 1 & A & $\bar{G}$ \\
\hline 23 & Promoter mutation (position - 29) & $\beta$ & -29 & 1 & $A$ & G \\
\hline
\end{tabular}

*In each sample, the same mutation was identified whether the sequencing template was MDA product or DNA isolated using the column method (see methods). $\mathrm{Hb}$, haemoglobin; MDA, multiple displacement amplification. 


\section{Take home messages}

- Multiple displacement amplification (MDA) produced large quantities of DNA in clinical specimens requiring haemoglobin gene sequencing

- The amplification procedure was extremely easy and took just four hours

- There was $100 \%$ concordance for detection of a variety of point mutations in the $\alpha 1, \alpha 2$, and $\beta$ globin genes when compared with genomic DNA isolated using column technology

- The MDA technique is useful for overcoming the problem of insufficient genomic DNA in clinical specimens requiring haemoglobin gene sequencing and could be useful for other clinical applications

did not hinder the sequencing application being tested and additional purification steps were not felt to be necessary. A previous report of MDA indicated that the method results in an average product length of $10 \mathrm{~kb}$, with a range from 2 to $100 \mathrm{~kb} .^{3}$ Agarose gel analysis of the MDA products in our study indicated that the average DNA length obtained was probably longer $(>20 \mathrm{~kb})$, but otherwise appeared consistent with predicted results. We also found that as little as three hours of amplification was sufficient to produce ample DNA for our purposes, which shortened the procedure time considerably, so that the entire amplification procedure required only approximately four hours (less than one hour of hands on technician time and three additional hours for incubation).

\section{"We found that as little as three hours of amplification was sufficient to produce ample DNA for our purposes, which shortened the procedure time considerably"}

We feel that our sequencing results were 100\% specific because the mutations identified are all previously reported haemoglobin abnormalities, the same mutation was detected using sequencing of both DNA strands, the remainder of the sequence in each case showed a normal haemoglobin gene sequence, and there was 100\% concordance with the results obtained using genomic DNA isolated by a standard column method as the sequencing template. Thus, our results indicate that the MDA technique is sufficiently reliable for amplification of peripheral blood samples before haemoglobin sequencing. Previous reports provide evidence to suggest that MDA is a robust and accurate technique, superior to PCR based genomic amplification methods. ${ }^{3-5}$ The error rate of $\phi 29$ polymerase is estimated to be only $1 / 10^{6}-10^{7}$, compared with approximately $3 / 10^{4}$ for Taq polymerase, ${ }^{6}$ and $\phi 29$ shows less amplification bias than Taq. ${ }^{3}$ Although our clinical test for globin gene sequencing uses PCR, errors caused by Taq polymerase do not appear to be frequent enough to confuse test interpretation. The main goal of our study was to verify the previous claims of $\phi 29$ enzyme fidelity in the context of our specific clinical needs.

Although we have only tested the MDA method in the specific clinical application of haemoglobin gene sequence analysis, we feel that MDA should be equally useful in a wide variety of clinical applications using small numbers of nucleated cells from essentially any source. However, our search of the English language literature revealed no previous reports of MDA applications for routine clinical testing.

\section{ACKNOWLEDGEMENTS}

We sincerely thank K S Kubik and J A Rolfing, clinical technicians in the Mayo Clinic hematopathology hemoglobin analysis laboratory, for their contributions to the sequencing data.

\section{Authors' affiliations}

M Mai, J D Hoyer, R F McClure, Division of Hematopathology, Department of Laboratory Medicine and Pathology, Mayo Clinic, Rochester 55905, USA

\section{REFERENCES}

1 Cheung V, Nelson S. Whole genome amplification using degenerate oligonucleotide primer allows hundreds of genotypes to be performed on less than one nanogram of genomic DNA. Proc Natl Acad Sci U S A 1996;93:14676-9.

2 Zhang L, Cui X, Schmitt K, et al. Whole genome amplification from a single cell: implications for genetic analysis. Proc Natl Acad Sci U S A 1992;89:5847-51.

3 Dean FB, Hosono S, Fang L, et al. Comprehensive human genome amplification using multiple displacement amplification. Proc Natl Acad Sci U S A 2002;99:5261-6.

4 Hosono S, Faruqui AF, Dean FB, et al. Unbiased whole genome amplification directly from clinical samples. Genome Res 2003;13:954-64.

5 Lage JM, Leamon JH, Pejovic T, et al. Whole genome analysis of genetic alterations in small DNA samples using hyperbranched strand displacement amplification and array-CGH. Genome Res 2003; 13:294-307.

6 Esteban J, Salas M, Bianco L. Fidelity of $\phi 29$ DNA polymerase. Comparison between protein-primed initiation and DNA polymerization. J Biol Chem 1993;268:2719-26. 